\title{
TENTOONSTELLING: GANDHARA
}

In 2001 keek de wereld geschokt toe hoe de Taliban de reusachtige Boeddha's van Bamiyan de lucht in lieten springen. Deze rotssculpturen waren late voorbeelden van de Gandhara-cultuur. Aan deze cultuur, die zijn hoogtepunt beleefde in de eerste tot en met de vijfde eeuw en als kerngebied het huidige Noordwest-Pakistan had, is nu in Bonn en vervolgens in Berlijn en Zürich, een grote overzichtstentoonstelling gewijd.

De kunst van Gandhara is bijna geheel boeddhistisch. Toch doet ze westerlingen zeer vertrouwd aan. Dat komt omdat Gandhara een ware smeltkroes van culturen was. In 325 v.Chr. veroverde Alexander de Grote het gebied. Zijn opvolgers moesten Gandhara weliswaar weer snel prijsgeven, maar de hellenistische invloeden bleven een zware stempel drukken. Gandhara lag immers aan de zijderoute en dus bleven er ook later intensieve handelscontacten bestaan met de Romeins-Hellenistische wereld. Zo ook met de Iraanse, Centraal-Aziatische en verder oostelijk gelegen culturen.

Het boeddhisme bereikte Gandhara vanuit het zuiden, vanuit India. De Gandhara-cultuur was op religieus gebied tolerant en kende vele goden. Toch hebben de kunstenaars zich vooral gericht op de verbeelding van de boeddhistische leer. De Boeddha werd aanvankelijk alleen door symbolen weergegeven, maar rond het begin van onze jaartelling kreeg hij in Gandhara voor het eerst een menselijk gezicht. En dat gezicht was opvallend Westers. De kunst van Gandhara importeerde uit het Westen de naturalistische weergave van de menselijke figuur, de contraposto en architectuurmotieven, zoals de klassieke zuilenorde, door eroten gedragen guirlandes en arcaden. Dat leverde fascinerende beelden op, zoals een bodhisattva met halflang krullend haar en een gespierde torso gehuld in een antieke toga. Alleen het vlassige snorretje en de rijke sieraden verraden de Oosterse herkomst. Prachtig zijn de gebeeldhouwde friezen met verschillende scènes uit het leven van de Boeddha, gescheiden door klassieke zuilen met Korinthische kapitelen. Op het eerste gezicht zouden het zo fragmenten van een Romeinse sarcofaag kunnen zijn.

Zeer illustratief is een serie figurenfriezen die op de tentoonstelling te zien is. De oudste tonen een rij met mannen en vrouwen in klassiek gewaad. Sommige mannen hebben een halfnaakte dame op schoot. Er wordt wijn geschonken en al met al is het een echt dionysisch tafereel. Op het laatste fries zien we een latere, Oosterse variant. De klassicke figuren laven zich niet langer aan de drank, maar brengen nu een bloemenofferande. 


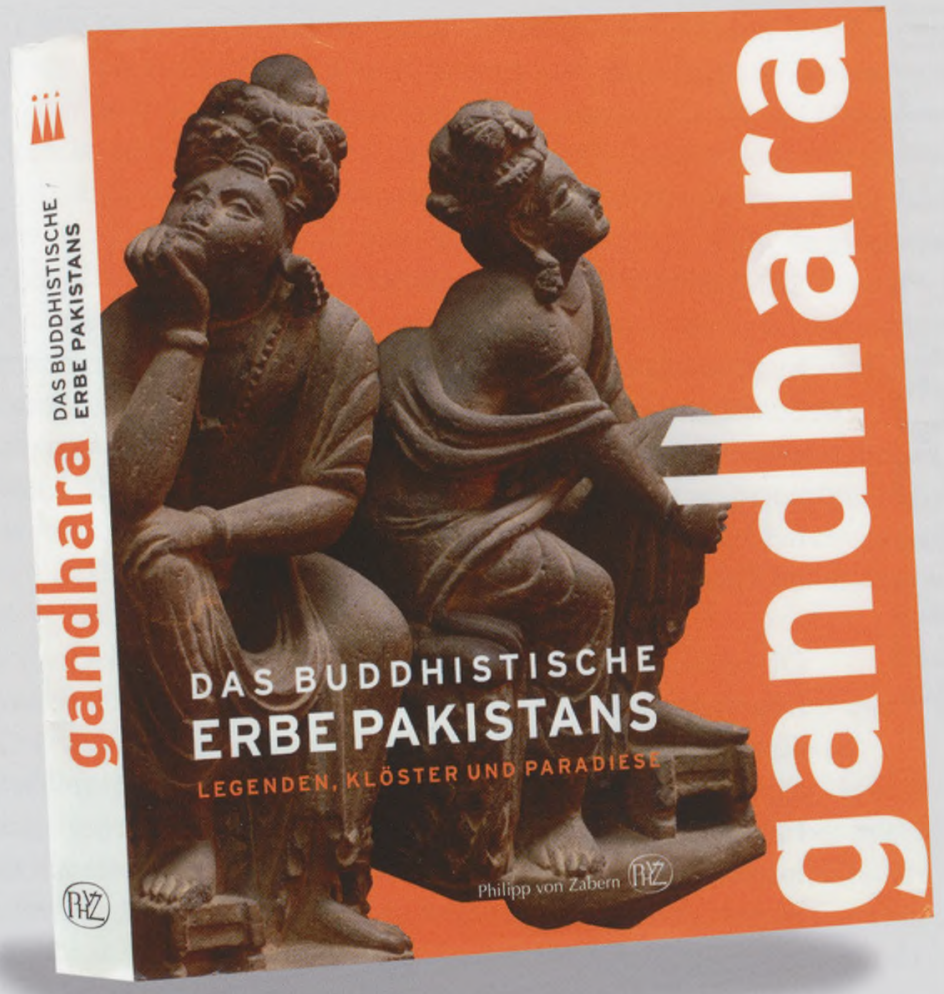

bewonderen zijn. Het is zeer de moeite waard deze indrukwekkende tentoonstelling te bezoeken. Tip: bekijk eerst de inleidende film die halverwege de expositie wordt vertoond: een prachtige inleiding op de ongehoorde rijkdom en verfijning van deze uiterst kosmopolitische cultuur.

- Gandhara - Das Buddhistische Erbe Pakistans. Legenden, Klöster und Paradiese. Kunst- und Ausstellungshalle der Bundesrepublik Deutschland, Bonn 21 november 2008 tot 15 maart 2009 Martin-Gropius-Bau, Berlijn 9 april tot 10 augustus 2009 Museum Rietberg, Zürich 6 september 2009 tot 3 januari 2010 